\title{
Arthropod Pests of Pear (Pyrus pyrifolia, Nakai) in Central Horticulture Centre, Kirtipur, Kathmandu, Nepal
}

\author{
Neelam Bajrachharya and Urmila Dyola \\ Central Department of Zoology, TU, Kirtipur, Kathmandu, Nepal \\ For correspondence: shakyaneelam68@yahoo.com, dyolaurmila@gmail.com
}

\begin{abstract}
Arthropod pests cause serious threats to pear orchards, resulting heavy reduction in their yield. The present study focused on the arthropod pests of Pear (Pyrus pyrifolia, Nakai), in the Pear orchard of Central Horticulture Centre, Kirtipur, Kathmandu. It was carried out in two seasons: Spring and Summer of 2012. The pests were collected through different methods such as hand picking, knock down process, beating process, sweeping and use of aspirator, depending upon the size of pests. The statistical analyses were performed at 95\% confidence level in R-Software (R-Console version2.15.2).

Altogether, 12 species of pests belonging to 11 families were observed during the study. The results showed that the pest's population was independent to months $\left(\mathrm{X}^{\wedge} 2=7.663, \mathrm{df}=5, \mathrm{P}+0.175\right)$, seasons $\left(\mathrm{X}^{\wedge} 2=0.188, \mathrm{df}=1, \mathrm{P}+0.664\right)$, and sites $(\mathrm{F}=0.446, \mathrm{df}=2, \mathrm{P}=0.652)$, however, population density of pests was higher in June (409) and summer (966). Spider mite (Tetranychus spp.), Aphids (Aphis spp.), Thrips (Scirtothrips spp.) Tortoise beetle (Metrona spp.) and Fruitfly (Dacus spp.) were the common pest species and the most dominant one was the Spider mite (Tetranychus spp.), occurring almost in all months, seasons and sites. The overall diversity index of pear pests was high, i.e, 0.800, however regarding individual species diversity index and dominance index, Spider mite (Tetranuchus spp.) had higher diversity indices, followed by Tortoise beetle (Metriona spp.), Fruit fly (Dacus spp.) and the least was observed in Click Beetle (Agriotes spp.). Although the pest population is independent to months and seasons, the present study showed that pear plants were more affected by pests during hot and warm season.
\end{abstract}

Keywords: Click beetle, Fruit fly, Pear orchard, Spider mite, Tortoise beetle

\section{Introduction}

Pear is commonly a medium sized tree or shrub of genus Pyrus (Riegel 2006), which generally reaches height of $10 \mathrm{~m}$ to $17 \mathrm{~m}$. The leaves of this plant are alternately arranged, simple and are $2-12 \mathrm{~cm}$ long. The flowers are white, rarely tinted yellow or pink and 2-4 cm in diameter and have five petals. The inflorescence is corymbose with five to seven flowers (Riegel 2006). It is one of the very important deciduous fruit plants of Nepal (Devkota 1999) which is also named as Pomaceous fruit. There are over 5,000 varieties of pears cultivated in temperate climate worldwide (Herbst 2001), of which the most important species for commercial production are European Pear (Pyrus communis) and Asian Pear (Pyrus pyrifolia), which is also known as Japanese pear or Oriental Pear (Beutel 1990 and Riegel 2006).

Nepalese Journal of Zoology | Online Volume 3 Issue 1 | November 2015 | Page 37 
In Nepal two kinds of pears are grown: Asian pear (Pyrus pyrifolia) and European pear (Pyrus communis) (Devkota 1990), former is also called oriental pear which is locally named as Naspati. Asian pears have a distinct pear like taste and a crisp texture. These pears ripen on the trees and they do not need cold storage period while European Pear are not rounder in shape and less crunchier than Asian Pear (Beutel 1990). The Asian Pear includes Japanese Pears, Chinese Pears, etc. The Japanese Pear includes different varieties like Shinsu, Shunko, Kosui, Hosui, etc. while European Pears are Barlett and Comice.

There are many threats in the cultivation of Pears. Generally, Pears are attacked by various kinds of pests such as Mites, Aphids, Thrips and Scale insects (CHC Annual Report 2011/12). Mites are known to migrate from host plants to other plants and vice-versa (Banerjee 1971) and are known as an important vector of plant viruses too (Gupta 1985, 1990). They may cause various types of direct damages to plants such as loss of chlorophyll, stunted growth, burnt appearance of leaves, heavy leaf fall and reduction in yield (Dhooria 1999). Generally, the Spider mite (Tetranychus) is susceptible to orchard plants. They suck sap from leaves, flowers and buds resulting in discoloration, appearance of silvery patches and drying of affected plants (Banerjee 1971).

Aphids are another recognized pests of Pear, which are sap sucking in nature (Sharma 2000). They are found in flowers, leaves and stem of Pear and are known to have transmitted more than 100 plant viruses (Sharma 2005). Similarly, Pear thrips and Scale insects are other common pests of Pear plant. Young thrips feed almost entirely on tender foliage and fruits (Daniel 1904), while scale insects make small, narrow or circular flat holes on stem and fruits of Pear (Evans 1984).

\section{Materials and Methods}

\section{Study area}

Central Horticulture Centre lies in Kirtipur Municipality, Kathmandu, which is $5 \mathrm{~km}$ south from Kathmandu valley. Geographically, it lies between $27^{\circ} 30^{\prime} \mathrm{N}$ latitude to $85^{\circ} 15^{\prime}$ E longitude, at an altitude of 1,320 m asl (CHC Annual Report 2011/12).

The station has mild temperature reaches up to $32^{\circ} \mathrm{C}$ during summer and falls below $-3^{\circ} \mathrm{C}$ during winter. The average rainfall during monsoon season is 1,025 $\mathrm{ml}$ (CHC Annual Report 2011/12).

Nepalese Journal of Zoology | Online Volume 3 Issue 1 | November 2015 | Page 38 


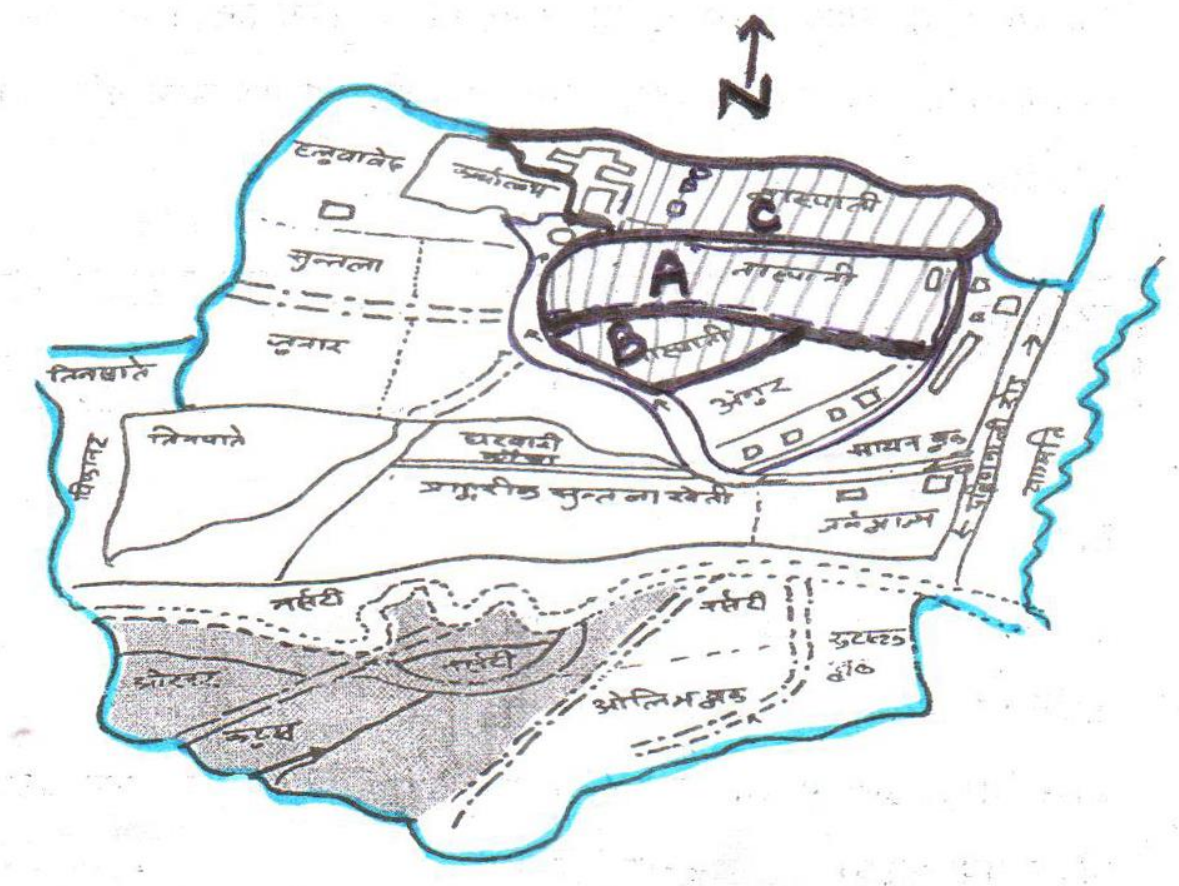

Figure 1. Map of Central Horticultural Centre, showing pear orchard (study area). Study design

The total area covered by CHC is 20 hectares, of which 11 hectares is occupied by 21 different fruit orchards, including Pears (Pyrus pyrifolia, Nakai) (CHC Annual Report 2011/12). Within this orchard area, three different sites: A, B and C were selected which are $20 \mathrm{~m}$ apart from one another. They cover an area of 42,831.25 sq. feet, 7,820.65 sq. feet and 33,594 sq. feet respectively. From each site, 10 different Pear plants were selected randomly and were marked. Then they were checked for the insect pests, by observing all parts of the plants such as stem, twig, leaf, blossoms, fruits, flowers and roots for two different seasons. They were observed through naked eyes and by hand lens, if needed. The sites were visited twice a month in the intervals of 15 days.

\section{Pest collection and preservation}

The pests which were large enough to be seen readily with naked eyes were collected by hand picking method with the help of forceps, and were put in vials containing $70 \%$ ethanol as preservative. Specimens like aphids, which occur in clusters were collected by using soft brush soaked in ethanol and also by knockdown process. Thrips and mites were also collected in similar way. Sweep net was used for collecting flying insect pests. Also, hanging vials with pheromones (Batocera compositae lure) was used for pest like Fruit flies. On the other hand, beating process and aspirator was used for the collection of small and light insects.

The general objective of this research was to study the arthropod pests of Pear (Pyrus pyrifolia, Nakai) in Central Horticulture Centre, Kirtipur.

\section{Data analysis}

One-way Analysis of Variance (ANOVA) was used to test the significant difference in number of pests observed in different sites. But, to test the significant difference in pest's number due to

Nepalese Journal of Zoology | Online Volume 3 Issue 1 | November 2015 | Page 39 
months and seasons, Kruskal-Wallis Rank Sum test was used. It is a non parametric test which is alternative to ANOVA. Since the data was not found normal, hence this test was performed. The statistical analyses were performed at $95 \%$ confidence level in R-Software (R-Console version 2.15.2).

On the other hand, the Shanon diversity index $(\overline{\mathrm{H}})$ was calculated by using the formula Shanon index of diversity $(\overline{\mathrm{H}})=-\sum(\mathrm{ni} / \mathrm{N}) \log (\mathrm{ni} / \mathrm{N})$

(Odum 1996)

Where, $\mathrm{ni}=$ Importance value for each species

$$
\mathrm{N}=\text { Total of importance value }
$$

Similarly, the index of dominance (c) was calculated as Index of dominance $(\mathrm{c})=\sum(\mathrm{ni} / \mathrm{N})^{2}$

(Odum 1996)

Where, $\mathrm{ni}=$ Importance value for each species

$\mathrm{N}=$ Total of importance value

\section{Results}

\section{Pests of pear}

Altogether 12 species of pear pests belonging to 11 families were observed in the Central Horticulture Centre, Kirtipur during the study. Among them, Family Chrysomelidae was represented by two species, whereas other families by single species (Table 1). The classification is based on Borror and Delong (1971).

Table 1. Pest species with their families

\begin{tabular}{|l|l|l|l|}
\hline S.N & \multicolumn{1}{|c|}{ Pests } & Family & Scientific Name \\
\hline 1 & Aphid & Aphidae & Aphis spp. \\
\hline 2 & Roaches & Blattodae & Unidentified \\
\hline 3 & Tortoise Beetle & Chrysomelidae & Metriona spp. \\
\hline 4 & Leaf Beetle & Chrysomelidae & Basilepta spp. \\
\hline 5 & Snout Beetle & Curculionidae & Unidentified \\
\hline 6 & San Jose Scale & Diaspididae & Quadraspidiotus spp. \\
\hline 7 & Click Beetle & Elatridae & Agriotes spp. \\
\hline 8 & Brown Marmorated Stink Bug & Pentatomidae & Halyomorpha spp. \\
\hline 9 & Fruit fly & Tephritidae & Dacus spp. \\
\hline 10 & Spider mite & Tetranychidae & Tetranychus spp. \\
\hline 11 & Thrips & Thripidae & Scirtothrips spp. \\
\hline 12 & Hornet & Vespidae & Vespa spp. \\
\hline
\end{tabular}

\subsection{Species diversity of pests}

Altogether 1,652 individuals of pests belonging to 12 species were observed during the study. Among them, Spider mite (Tetranychus spp.) was the most common pest of Pear. Similarly, the other frequently

Nepalese Journal of Zoology| Online Volume 3 Issue 1 | November 2015 | Page 40 
occurring pests were Aphids (Aphis spp.), Thrips (Scirtothrips spp.), Tortoise Beetle (Metriona spp.) and fruitfly (Dacus spp.) (Figure 2). Click Beetle (Agriotes spp.) was the least common species in Pear Orchard of CHC during the study.

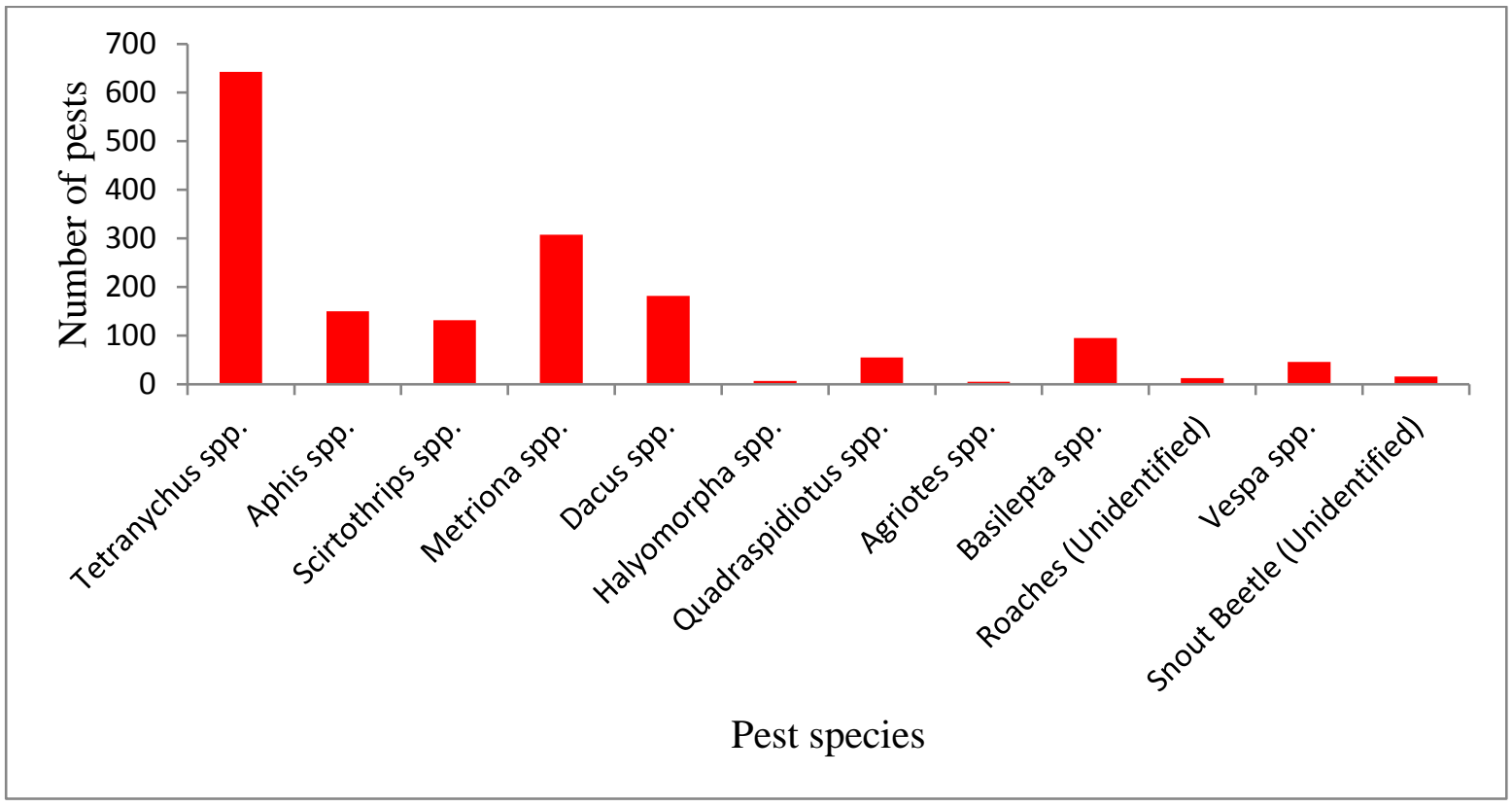

Figure 2. Pest species and their number.

Table 2. Species diversity of pests

\begin{tabular}{|l|l|l|l|l|l|l|}
\hline S.N & Pests & $\mathbf{n i}$ & $\mathbf{n i} / \mathbf{N}$ & $\mathbf{l o g} \mathbf{n i} / \mathbf{N}$ & Shanon Index & $\begin{array}{l}\text { Species } \\
\text { Dominance } \\
\sum(\mathbf{n i} / \mathbf{N})^{\mathbf{2}}\end{array}$ \\
\hline 1 & Tetranychus spp. & 643 & 0.389225 & -0.4097991 & $\mathbf{0 . 1 5 9 5 0 4 1 1 7}$ & $\mathbf{0 . 1 5 1 4 9 6 2 4 2}$ \\
\hline 2 & Aphis spp. & 150 & 0.090799 & -1.0419188 & 0.094605216 & 0.008244464 \\
\hline 3 & Scirtothrips spp. & 132 & 0.079903 & -1.0974361 & 0.0876886 & 0.006384513 \\
\hline 4 & Metriona spp. & 308 & 0.186441 & -0.7294593 & 0.136000891 & 0.034760126 \\
\hline 5 & Dacus spp. & 182 & 0.110169 & -0.9579387 & 0.105535615 & 0.012137317 \\
\hline 6 & Halyomorpha spp. & 7 & 0.004237 & -2.372912 & 0.010054712 & $1.79546 \mathrm{E}-05$ \\
\hline 7 & $\begin{array}{l}\text { Quadraspidiotus } \\
\text { spp. }\end{array}$ & 55 & 0.033293 & -1.4776474 & 0.049195281 & 0.001108422 \\
\hline 8 & Agriotes spp. & 5 & 0.003027 & -2.51904 & $\mathbf{0 . 0 0 7 6 2 4 2 1 3}$ & $\mathbf{9 . 1 6 0 5 2 E - 0 6}$ \\
\hline 9 & Basilepta spp. & 95 & 0.057506 & -1.2402864 & 0.071323978 & 0.003306946 \\
\hline 10 & $\begin{array}{l}\text { Roaches } \\
\text { (Unidentified) }\end{array}$ & 13 & 0.007869 & -2.1040667 & 0.016557426 & $6.19251 \mathrm{E}-05$ \\
\hline 11 & Vespa spp. & 46 & 0.027845 & -1.5552522 & 0.043306054 & 0.000775346 \\
\hline 12 & $\begin{array}{l}\text { Snout } \\
\text { (Unidentified) }\end{array}$ & 16 & 0.009685 & -2.0138901 & 0.019504988 & $9.38037 \mathrm{E}-05$ \\
\hline & Total & $\mathbf{1 6 5 2}$ & & & $\mathbf{0 . 8 0 0 9 0 1 0 9 2}$ & \\
\hline
\end{tabular}

Nepalese Journal of Zoology | Online Volume 3 Issue 1 | November 2015 | Page 41 
The overall diversity index of pear pests was high, i.e., 0.800, however, regarding individual species diversity index, Spider mite (Tetranychus spp.) had higher diversity index (0.1595), followed by Tortoise Beetle (Metriona spp.), Fruitfly (Dacus spp.) and so on. Among 12 species of Pear pests, Click Beetle (Agriotes spp.) had the lowest diversity index (0.0076). Similarly, the index of dominance was also higher in Spider mite (Tetranychus spp.), which is 0.1514 , followed by Tortoise beetle (Metriona spp.), Fruitfly (Dacus spp.) and so on. The Click Beetle (Agriotes spp.) was the lowest dominant pest species having index of dominance only 9.16052E-06 (Table 2).

\subsection{Monthly variation in number of pests}

Kruskal Wallis test revealed that there was no significant difference $\left(X^{2}=7.666, \mathrm{df}=5, \mathrm{P}=0.175\right)$ in pest number due to different months. However, their number gradually increases from March to June, peaked on this month and then decreasing onwards in the subsequent months. Clearly, the highest number of pests was observed in June (409) and the lowest in March (94) (Figure 2). Similarly, species richness was also high in June and also in July too. Out of 12 species recorded, the same number of species, i.e. 11 was found in June and July, which was the highest number of species recorded among six months (Figure 2). Regarding specific pests, Aphids (Aphis spp.) and Thrips (Scirtothrips spp.) were dominant in March and April, whereas, Spider mite was the most dominant pest species in the subsequent months; in fact, there was more or less same number of Spider mite (Tetranychus spp.) and Tortoise beetle (Metriona spp.) in July (Figure 3). In May and June, Spider mite (Tetranychus spp.) alone damaged more than 50 per cent of total damage, done by overall pests in Pear orchard of CHC.

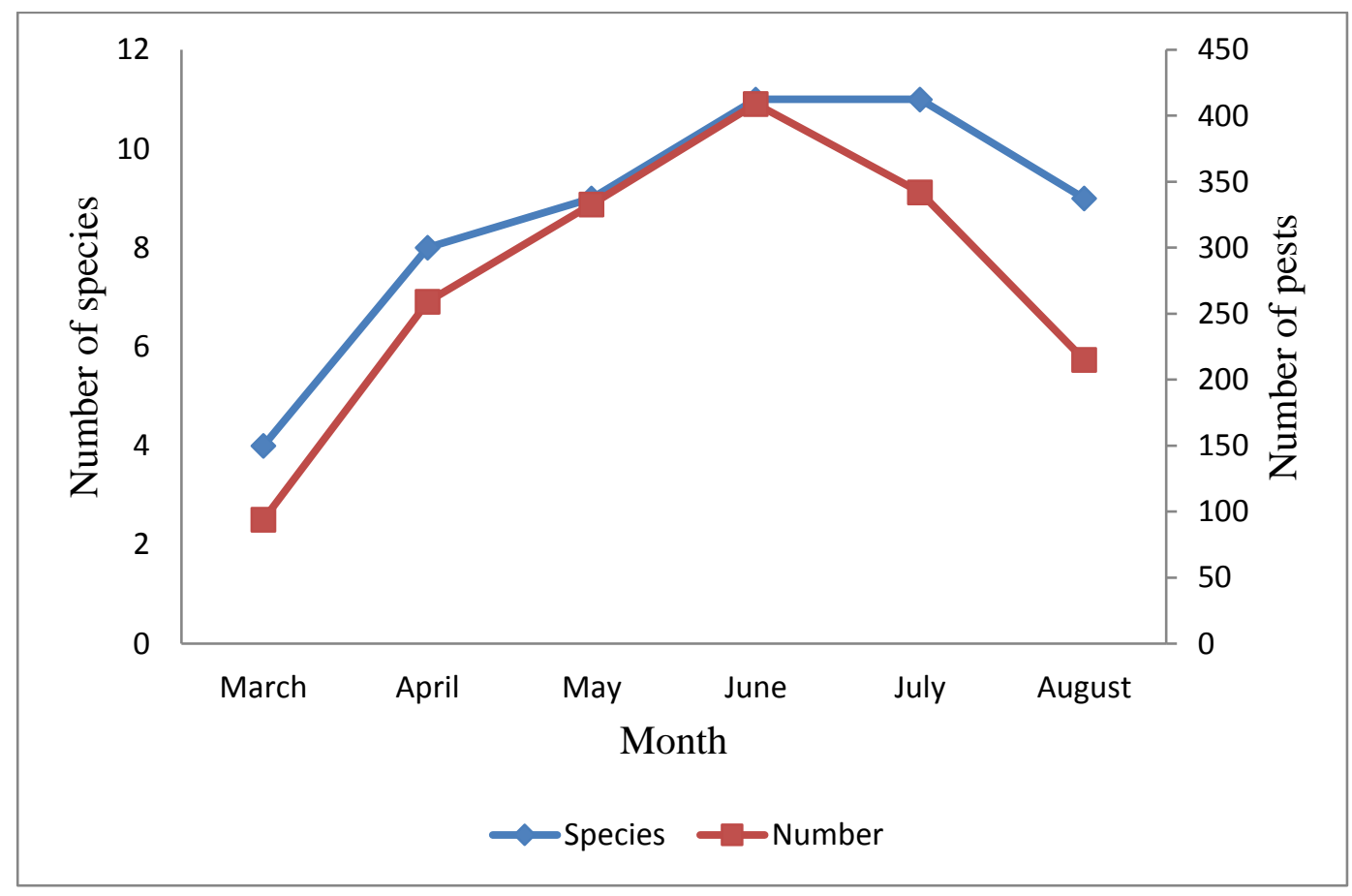

Figure 3. Monthly variation in species and number of pests.

Nepalese Journal of Zoology | Online Volume 3 Issue 1 | November 2015 | Page 42 


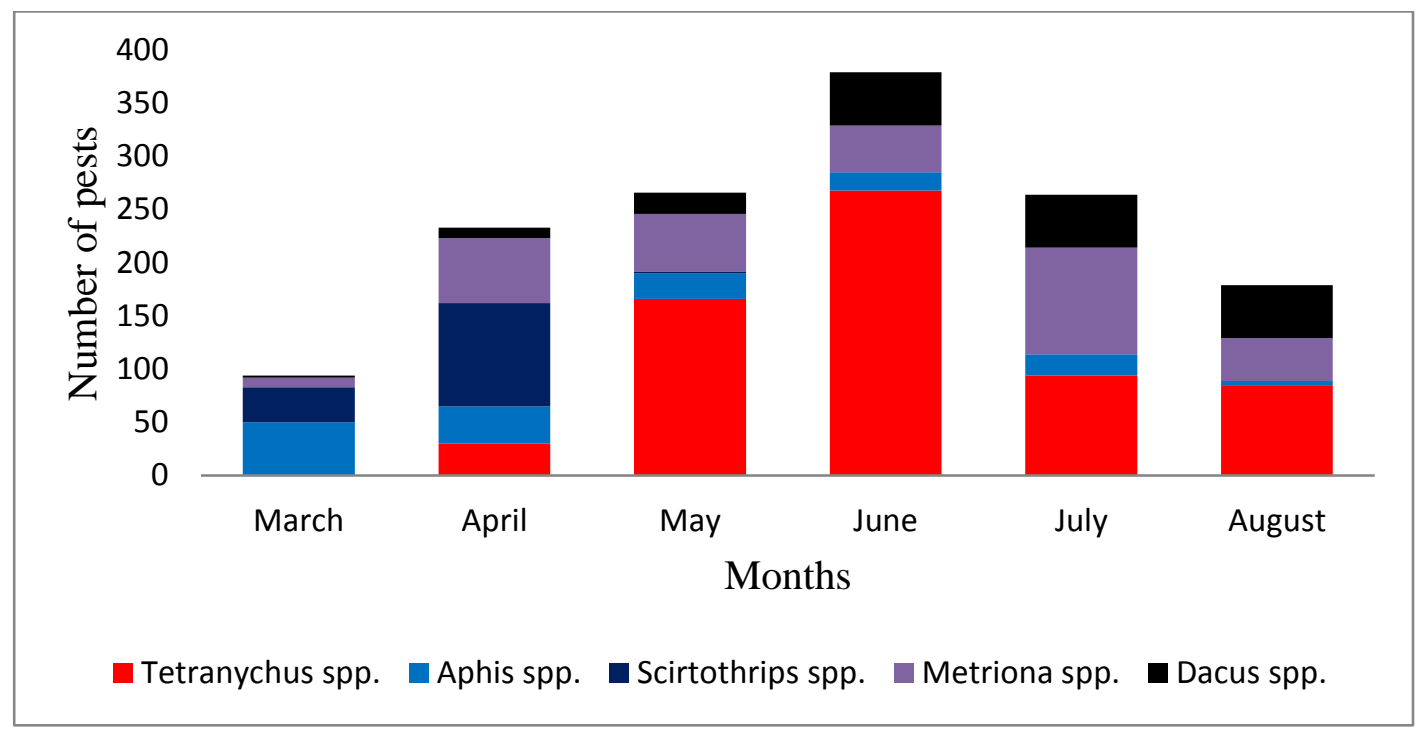

Figure 4. Monthly variation and species dominance.

\subsection{Seasonal variation and number of pests}

With variation in seasons, the number of Pear pests did not vary. Kruskal Wallis test showed that there was no significant difference $\left(\mathrm{X}^{2}=0.188, \mathrm{df}=1, \mathrm{P}=0.664\right)$ in number of pests in Pear plants due to different seasons. However, summer (966) had higher number of pests than the spring (686) (Table 3). But, among 12 pear pests recorded, summer had more number of species (11) than spring (9). Click Beetle (Agriotes spp.), Roaches (Unidentified) and Hornet (Vespa spp.) were absent in spring whereas, Thrips (Scirtothrips spp.) was not observed in summer during the study. In overall, Spider mite (Tetranychus spp.) was the most dominant pest species in both seasons.

Nepalese Journal of Zoology| Online Volume 3 Issue 1 | November 2015 | Page 43 
Table 3. Pests of Pear in two seasons

\begin{tabular}{|l|l|l|l|l|}
\hline SN & \multirow{2}{*}{ Pests } & Season & \multirow{2}{*}{ Total } \\
\cline { 3 - 4 } & Spring & Summer & \\
\hline 1 & Spider mite (Tetranychus spp.) & 196 & 447 & 643 \\
\hline 2 & Aphids (Aphis spp.) & 109 & 41 & 150 \\
\hline 3 & Thrips (Scirtothrips spp.) & 132 & 0 & 132 \\
\hline 4 & Tortoise Beetle (Metriona spp.) & 124 & 184 & 308 \\
\hline 5 & Fruitfly (Dacus spp.) & 32 & 150 & 182 \\
\hline 6 & $\begin{array}{l}\text { Brown Marmorated Stink Bug (Halyomorpha } \\
\text { spp.) }\end{array}$ & 4 & 3 & \\
\hline 7 & San Jose Scale (Quadraspidiotus spp.) & 21 & 34 & 7 \\
\hline 8 & Click Beetle (Agriotes spp.) & 0 & 5 & 55 \\
\hline 9 & Leaf Beetle (Basilepta spp.) & 59 & 36 & 5 \\
\hline 10 & Roaches (Unidentified) & 0 & 13 & 95 \\
\hline 11 & Hornet (Vespa spp.) & 0 & 46 & 13 \\
\hline 12 & Snout Beetle (Unidentified) & 9 & 7 & 46 \\
\hline & Total & 686 & 966 & 16 \\
\hline
\end{tabular}

\subsection{Variation in number of pests in different sites}

There was no variation in number of pests occurring in different sites. One-way ANOVA revealed that there was no significant difference $(\mathrm{F}=0.446, \mathrm{df}=2, \mathrm{p}=0.652)$ between number of pest species and sites. More or less same number of pests was observed in all sites. Spider mite (Tetranychus spp.), Aphids (Aphis spp.), Thrips (Scirtothrips spp.), Tortoise beetle (Metriona spp.) and Fruitfly (Dacus spp.) were the most common pest species, occurring in all sites. The median value of pest's number was more than 80 in all sites.

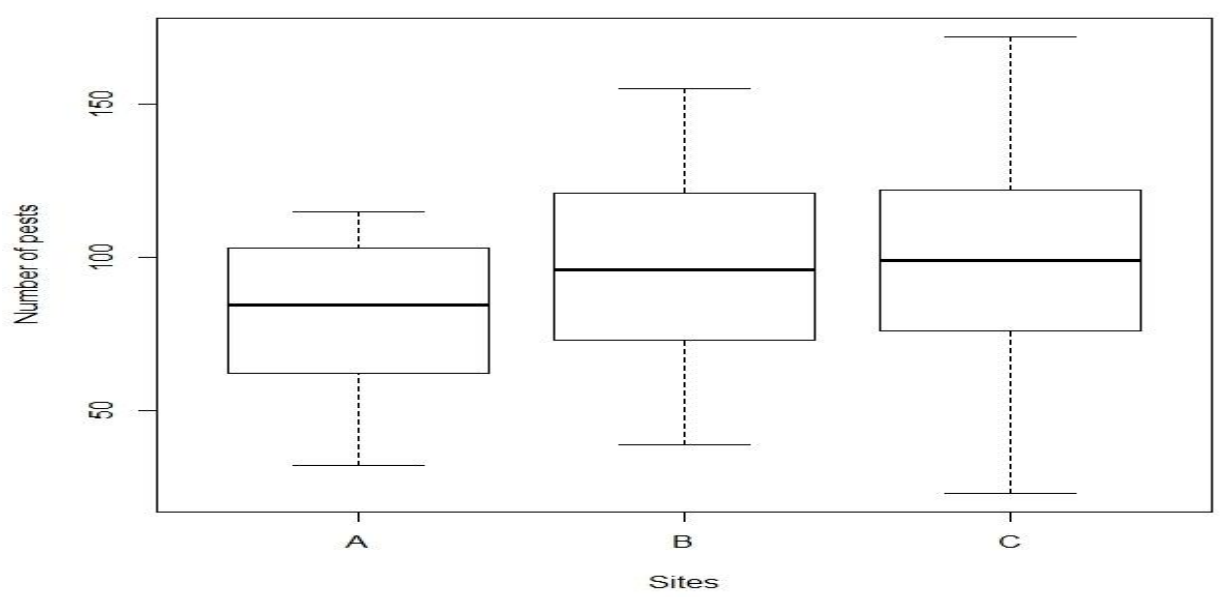

Figure 5. Box plot showing number of pests observed in three different sites (A, B and C). The dark line in the box plot represents the median or mid value and its arm represents the quartile value.

Nepalese Journal of Zoology | Online Volume 3 Issue 1 | November 2015 | Page 44 


\section{Discussion}

Species diversity is the ratio between number of species and "importance values" (number, biomass, productivity, and so on) of individuals (Odum 1996) in which it tends to be low in physically controlled ecosystem and high in biologically controlled ecosystems. Species Diversity Index (SDI) is the most frequently used tool by many scientists for measuring the species diversity (Parrotta et al. 1997, Whitford 1997). It is a numerical measurement of species and can express the diversity within communities and often used to compare the diversity of the species. In Central Horticulture Centre (CHC), the SDI of overall pear pests was high $(0.800)$, which shows stability in pest's ecosystem. But regarding individual diversity indices, both SDI and index of dominance were high in Spider mite (Tetranychus spp.) comprising 0.1595 and 0.1514 respectively (Table 2). On the other hand, Click Beetle (Agriotes spp.) was the least dominating pest species having dominance index only 9.16052E-06. As this study was carried out in spring and summer months, this might be cause for high number of Spider mite (Tetranychus spp.) during the study because the mite population was positively correlated with high temperature and low relative humidity (Putatunda and Tagore 2000, Mohamed Osman and Mahmoud 2008). Therefore, its SDI and dominance index were relatively high among other pests of pear.

Although the pests' population was statistically independent to months, however, the high number of pests was observed in June (409). It showed gradual increment from March to June, was peaked on June and their number gradually dwindled in the subsequent months (Figure 3). This result is in agreement with the findings of Dhooria and Bhutani (1983) and Putatunda and Tagore (2000), in which the pest population peaked during May to September and there was negligible population during December to March, as a result, their population was peaked in summer months. As temperature is generally high in summer months (May and June), this might be another cause for high density of pests in these months because the life cycle of most of the insect pests became functional or more active during hotter days (Pedigo 2002). Indeed, eggs overwinter and hatching occurs after onset of spring, i.e. when the environment became warm. Regarding specific pests in the present study, the density of Spider mite (Tetranychus spp.) was highest which is followed by Tortoise beetle (Metriona spp.), Fruitfly (Dacus spp.), Aphids (Aphis spp.), Thrips (Scirtothrips spp.) and so on (Figure 2). The annual report of CHC Annual Report (2011/12) also mentioned Spider mite (Tetranychus spp.) as a pest of pear, including other species such as Hornet (Vespa spp.), Thrips (Scirtothrips spp.) and Fruitfly (Dacus spp.) which resembles with our study.

There was no statistical variation in pest population due to seasons, but more number of pests was observed in summer (966) than in spring (686). Temperature is one of the most important factors that have great effect on pests (insects) developmental rates primarily because of their poikilothermic adaptation. As environmental conditions become more and more warm, their biological processes and hence the life cycle proceeds more well (Pedigo 2002). Therefore, due to higher temperature in summer months, pest population generally becomes higher. This was observed during our study as well. Regarding specific pests, Spider mite (Tetranychus spp.) alone dominated the both seasons in present study, but its number was higher in summer which is similar to the study of Portor (2007) and Murray and Alston (2011), where they argued that Spider mites reproduce during hot and dry conditions of summer and thus their density was high in this period. In contrast, Krewer and Bertrand (2012) discussed that Red Spider mites attack pears during bloom in great proportion, i.e. at spring which contradicts with our findings. This may be because we had not gone to species level, as perhaps the species of Spider mites were different.

Nepalese Journal of Zoology | Online Volume 3 Issue 1 | November 2015 | Page 45 
Similarly, Alston and Reding (2011) revealed that pear is the most sensitive to mite feeding than other stone fruits. Chhillar and Kumar (2000) also argued that phytophagous mites occur almost in all ornamental crops, including pear, reducing sharp decrease in yield and serving as a vector of several plant diseases. The annual report of CHC (2011/12) also mentioned that there was a noticeable decrease in the yield of pear due to damage done by mites. Mite feeding may cause leaf curling, leaf burning and defoliation (Gupta 1990), that lead to decrease in total yields. During our visit too, leaf curling and burning in some pear plants were observed. This was more noticed in June and July; because perhaps their population is at peak in these months which directly correlates to nature of damage.

The study further showed that Thrips (Scirtothrips spp.) were more dominant during first two spring months (Table 3). Booth (2007) discussed that pear is one of the host trees of Thrips, in which it overwinters in the soil and the adult Thrips emerge from soil in early spring and begin feeding just as the buds begin to expand, which is similar to our results. Therefore, this might be a cause for high density of Thrips during spring months. Gardescu (2008) also discussed that adult Thrips emerge from their underground cells in spring when soil temperature become warm, therefore, their population seem higher in spring than other season of a year.

On the other hand, there was no significant difference in the number of pests in different sites (Site A, B and C) of pear orchard of CHC (Figure 5). In all sites, Spider mite (Tetranychus spp.), Aphids (Aphis spp.), Thrips (Scirtothrips spp.), Tortoise beetle (Metriona spp.) and Fruitfly (Dacus spp.) are the common pests that were recorded mostly. The three sites are no more than $20 \mathrm{~m}$ from one another, so that any insect pest whether flying or non-flying could easily migrate from one to other. Similarly, the physical location of these sites is also similar; all are facing towards east and somehow sloppy in nature. There did not exist any physical or topographical difference among these sites, though they occupy different area. As a result, the pest composition seemed similar in all sites.

Results showed that some pests such as Fruit fly (Dacus spp.), Hornet (Vespa spp.) and Tortoise beetle (Metriona spp.) were more in number during fruiting season of pear. The annual report of CHC (2011/12) also mentioned Hornet (Vespa spp.) and Fruitfly (Dacus spp.) as a destructive pests of pear during fruiting period. This study seemed close to this annual report of $\mathrm{CHC}$, where the density of Hornet (Vespa spp.), Fruitfly (Dacus spp.) and beetles were comparatively high in summer, a fruiting time of pear. As these species prefer fruits than other parts of plants, hence this might be a cause for these species to occur more in fruiting trees of pear.

\section{Acknowledgements}

We would like to express our sincere gratitude to Central Department of Zoology. Similarly, we express our thanks to Mr Devendra Kumar Saraf (Farm Manager) and Dr Janardan Khadka (Soil Scientist), Central Horticulture Centre, Kirtipur, Kathmandu. Also, our special thanks go to Mr Yam Aryal, Central Department of Zoology.

\section{References}

Alston, G. D. and Reding, E. M. 2011. European Red Mite. Uthah State University Extension and Uthah Plant Pest Diagnostic Laboratory, ENT 152-05.

BA. 1993. Biodiversity Act. Import Health Standard: Fresh Fruit/Vegetables. Korean Pears, Pyrus pyrifolia from the Republic of Korea: 1-16.

BA. 2003. Biosecurity Australia. Pear pests. http:// www.daff.gov.au, retrieved on 13 January 2014.

Nepalese Journal of Zoology | Online Volume 3 Issue 1 | November 2015 | Page 46 
Banerjee, B. 1971. Concepts of pest control today. Two and A. Bud 18: 50-52.

Beutel, J. A. 1990. Asian Pear. In Janick and J. E. Simon (eds). Advances in new Crops: 304-309. Timber Press, Portland.

Booth, D. C. 2007. Pear Thrips Identification, Biology and Management. Bartlett Tree

Research

Laboratories technical Report. http:// www.agr.gc.ca, retrieved on 21 December 2013.

Borror, D. J. and Delong, D. W. 1971. An introduction to the study of insect. Third edition. Halt, Rienbart and Winston Inc. USA.

Chakrabarti, S. 2005. Diversity of Aphid fauna and their host plant diversity in western and northwest Himalaya, India. In: Hartmann, M and J. Weipert (Eds). Biodiversity and Naturausstattung in Himalaya II. Verein der Freunde und Forderer des Naturkundemuseums Erfurt e. V., Erfurt: 23-38.

CHC. 2011/12. Central Horticulture Centre. Annual Report published by Central Horticulture Centre, Kirtipur, Kathmandu.

Cox, L., Alston, D. and Steffan, S. 2003. Apple and Pear insect control for Homeowners (codling Moth), Utah Pests Fact Sheet.

Daniel, D. M. 1904. The Pear Thrips. Entomological news. http:// archive.org/stream/cu31924002838385/cu 319240028385.djvu.txt, retrieved on 29 January 2014.

Devkota, L. 1999. Deciduous Plant Production of Nepal, FAO Corporate Document Repository. http:// www.fao.org/docrep/004/ab985e/ab985e08.htm, retrieved on 13 January 2014.

Dhooria, M. S. 1999. Observations on the status of phytophagous and predacious mites on different ornamental plants. Punjab. J. Acarol 14: 88-89.

Dhooria, M. S. and Butani, D. K. 1983. Seasonal incidence of citrus mites, Eutetranychus orientalis and its predators. Indian J. Acarol 7: 59-62.

Edge, V. 1988. Organolin resistance in Tetranychus urticae in Australia. J. Evon. Entmi 79: 1477-1483.

Esterby, S. R. 2006. Variables related to Codling Moth abundance and the efficacy of the Okanagan Sterile Insect Release Program. The Canadian Journal of Statistics 34(3): 1-7.

Evans, J. W. 1984. Insect pest and their control. Asiatic Publishing House. Second Edition.

Gardescu, S. 2008. Sugar Maple and the Pear Thrips. Insect Diagnostic Laboratory. Cornell University, 4140 Comstock Hall, Ithaca, NY 14853.

Ghosh, S. P. 1999. Deciduous fruit production of India. FAO Corporate Document Repository.

Gupta, S. K. 1985. A Handbook of Plant Mites of India. Zoological Survey of India, Culcutta: 1-520.

Gupta, S. K. 1990. Annual Report. All India Coordinated Research Project on Agricultural Acarology. ICAR: 1-256.

HAL. 2003. Horticulture Australia Limited. Industry Profiles. http:// www.horticulture.comau/aboutas/contacts, retrieved on 23 December, 2013.

Herbst, S. T. 2001. The new food lover's companion. Comprehensive Definitions of Nearly 6,000 Food, Drinks and Culinary Terms. Third Edition. Hauppauge. NY: Barran's Educational Series. ISBN 0764112589.

Nepalese Journal of Zoology| Online Volume 3 Issue 1 | November 2015 | Page 47 
Krewer, G. and Bertrand, P. 2012. Home Garden Pears. Circular 742: 1-4.

Mohamed Osman, M. A. E. and Mahmoud, M. F. 2008. Seasonal Abundance Patterns of Insects and Mites on Pear Trees during the Blooming and Fruiting Seasons at Ismailia Governorate, Egypt. Tunisian Journal of Plant Protection 3: 47-58.

Murray, M and Alston, D. 2011. The Backyard Orchardist Fruit Pests: Pear. Utah Pests Fact Sheet: 1-3.

Neupane, F. B. 1973. Bali Biruwa ka Satru ra Tinko Roktham (Nepali). Fourth Edition. Sajha Publication, Lalitpur.

Odum, E. P. 1996. Fundamentals of Ecology. Third Edition. Natraj Publishers, Dehradun, India.

Parrotta, J. A., Knowles, O. H. and Wunderle, J. M. 1997. Development of floristic diversity in 10-yearsold restoration forests on a bauxite mined site in Amazonia. Forest Ecology and Management 99: 21-42.

Pedigo, L. P. 2002. A textbook of Entomology and Pest Management. Prentice Hall of India, New Delhi, India.

Portor, M. F. 2007. Spider mites on landscape plants. http:// www.2.ca.uky.edu/entomology/entfacts/ef438.asp, retrieved on 23 January 2014.

Putatunda, B. N. and Tagore, A. 2000. Effect of temperature, relative humidity and sunshine hours on mite population. CCS Haryana Agricultural University, Hisar-125004.

R Development Core Team. 2013. R: A Language and Environment for Statistical computing version 2.15.2. R Foundation for Statistical Computing, Viena, Austria. (http://www.R-project.org ).

Riegel, M. 2006. Pear: Pyrus communis, Pyrus pyrifolia. University of Georgia. http:// www.newworld.encyclopedia.org, retrieved on January 8, 2014.

Sakma, T., Tomiyasu, T. and Pandey, F. M. 1997. Phalphulma lagne pramukh rog tatha kiraharu ra tinka roktham. A report published by Central Horticulture Centre, Kirtipur, Kathmandu, Nepal. Second edition.

Sharma, K. C. 2000. Aphids of Nepal. Sajha Prakashan Publication House, Nepal.

Shutova, N. N. 1970. The Pear Moth, Numonia pyrivorella, Guide to quarantine pests, disease and weeds. Moscow, Russia, Kolas: 69-70.

Unruh, T. 2010. Personal communication regarding parasitoid species found on scale in early 1990. http:// www.jeery.tfrec.wsu.edu/opm/display/species, retrieved on 11 january 2014.

Whitford, W. G. 1997. Desertification and animal biodiversity in the desert grassland of North America. Journal of Arid Environments 37 (4): 709-720.

Yasuda, F., Yamamoto, K., Jinno, Y., Watanabe, H. and Izawa, H. 2002. Pest control of Japanese Pear by ground stationary sprinkler systems. Acta Hort. (ISHS) 587: 675-683. http:// www.actahort.org/books/587-90.htm, retrieved on December 22, 2013.

Nepalese Journal of Zoology | Online Volume 3 Issue 1 | November 2015 | Page 48 